\title{
Effects of abiotic stress on biomass and anthocyanin production in cell cultures of Melastoma malabathricum
}

\author{
L. K. CHAN ${ }^{1}$, S. S. KOAY ${ }^{1}$, P. L. BOEY ${ }^{2}$ and A. BHATT ${ }^{*}$
}

School of Biological Sciences ${ }^{1}$, and School of Chemical Sciences ${ }^{2}$, Universiti Sains Malaysia, 11800 Penang, Malaysia

\begin{abstract}
Plant cell cultures could be used as an important tool for biochemical production, ranging from natural coloring (pigments) to pharmaceutical products. Anthocyanins are becoming a very important alternative to synthetic dyes because of increased public concern over the safety of artificial food coloring agents. Several factors are responsible for the production of anthocynin in cell cultures. In the present study, we investigate the effects of different environmental factors, such as light intensity, irradiance (continuous irradiance or continuous darkness), temperature and medium $\mathrm{pH}$ on cell biomass yield and anthocyanin production in cultures of Melastoma malabathricum. Moderate light intensity (301- 600 lux) induced higher accumulation of anthocyanins in the cells. The cultures exposed to $10-\mathrm{d}$ continuous darkness showed the lowest pigment content, while the cultures exposed to 10 - $d$ continuous irradiance showed the highest pigment content. The cell cultures incubated at a lower temperature range $\left(20 \pm 2{ }^{\circ} \mathrm{C}\right)$ grew better and had higher pigment content than those grown at $26 \pm 2^{\circ} \mathrm{C}$ and $29 \pm 2^{\circ} \mathrm{C}$. Different medium $\mathrm{pH}$ did not affect the yield of cell biomass but anthocyanin accumulation was highest at $\mathrm{pH} 5.25-6.25$.
\end{abstract}

Key terms: irradiance, medium $\mathrm{pH}$, photoperiod, temperature, Melastoma malabathricum

\section{INTRODUCTION}

Melastoma malabathricum L. (Family Melastomaceae), is a common shrub that grows in previously cleared land and waste places. This plant is an important dyeproducing plant. Besides having bright attractive colours and high water solubility, anthocyanins were found to possess antioxidant, anti-inflammatory, anticarcinogenic, antiatherogenic, antibacterial and antiviral properties (Mazza 2000). The demand for natural food colorants in place of synthetic colorants is increasing worldwide. Anthocynin is one of the important natural dyes, with high market value (US\$ $1250-2000 / \mathrm{kg}$ ) (Delgado-Vargas and Parades-Lopez 2003). The potential to produce anthocyanins through plant cell cultures is being considered as a valuable alternative to the use of synthetic dyes. Plant cell cultures can provide a year-round supply of the product under controlled conditions (Deroles et al., 2006). Production of anthocyanins via plant cell cultures from various plant species has been successful, such as with Catharanthus roseus (Filippini et al., 2003), strawberry (Mori et al., 1993) and purple sweet potato (Terahara et al., 2004). Hence, the potential to produce anthocyanins from M. malabathricum through plant cell cultures is a valuable alternative.

Our previous study indicated that anthocyanin could be produced from the callus and cell suspension cultures of $M$. malabathricum (Chan et al., 2008). To optimize the production of anthocyanin we realized that abiotic factors play an important role on cell biomass yield and anthocyanin production in cell suspension cultures of $M$. malabathricum. Therefore, the present study aims to investigate the 
effect of environmental factors i.e., light, photoperiod, temperature and medium $\mathrm{pH}$ on cell biomass yield and anthocyanin production of $M$. malabathricum.

\section{MATERIAL AND METHODS}

Establishment of stable cell suspension cultures of $\mathrm{M}$. malabathricum

Initiation and establishment of cell suspension culture was based on the method described by Chan et al (2008). The cells were subcultured at 9-day intervals and maintained in liquid Murashige \& Skoog (1962) MS medium, supplemented with $0.25 \mathrm{mg} \mathrm{dm}^{-3}$ benzyladenine (BA) and 0.5 $\mathrm{mg} / \mathrm{L}$ NAA, the cell proliferation medium according to a previous study by Chan et al (2008). A sterile stainless steel sieve, with $850 \mu \mathrm{m}$ pore size, was used to separate the cells during subculture. Individual cells or small cell aggregates that passed through the sieve (with a diameter $<850 \mu \mathrm{m}$ ) were subsequently filtered using an air suction pump (Aspirator 3A-S-Eyela, Raikakikai Co. Ltd, Tokyo) to remove the medium. The cell cultures were placed on an orbital shaker (New Brunswick Scientific, Edison, NJ, USA) at $120 \mathrm{rpm}$ in a culture room maintained at $24 \pm 2^{\circ} \mathrm{C}$ under continuous illumination with cool white fluorescent tubes with a light intensity of $500-1000$ lux. After 9 days, the cells were harvested and used as plant materials for subsequent studies.

\section{Effect of light intensity}

A cell biomass of $0.75 \mathrm{~g}$ obtained from the cell suspension stock, which was subcultured every 9 days in liquid MS medium $+0.25 \mathrm{mg} / \mathrm{L} \mathrm{BA}+0.5 \mathrm{mg} / \mathrm{L} \mathrm{NAA}$, was transferred into $100 \mathrm{~mL}$ Erlenmeyer flasks, each containing $20 \mathrm{~mL}$ liquid medium of the same composition. The $\mathrm{pH}$ of the medium was adjusted to 5.75 before autoclaving. Light intensities were measured using a lux meter with the light detector placed at the level of the liquid medium on the shaker. All prepared cell cultures were placed on the same shaker
(New Brunswick Scientific, Edison, NJ, USA), fitted with two fluorescence tubes from the top, supplying a range of light intensities up to $1200 \mathrm{lux}$. The light intensities were divided into four categories, i.e. 0 - 300 lux, 301- 600 lux, $601-900$ lux and $901-1200$ lux. The cells were harvested after 9 days of culture. The fresh cell biomass was determined using the digital balance (Denver Instrument XL-410, U.S.A.) and the dried cells were recorded after freeze drying. Pigment content and pigment production were determined as stated in the section below.

\section{Effect of continuous irradiance or continuous darkness}

To determine the effect of the photoperiod, a cell biomass of $0.75 \mathrm{~g}$ obtained from the cell culture stock was inoculated into each $100 \mathrm{~mL}$ Erlenmeyer flask containing $20 \mathrm{~mL}$ of cell proliferation medium. The cultures were divided into four groups. Each group was exposed to different photoperiods with light intensities maintained within the range of 301 - 600 lux. The four photoperiods were: 10 days of continuous exposure to illumination (L_10d), 10 days of continuous darkness (D_10d), 5 days of darkness followed by 5 days of exposure to illumination (D_5d L_5d) and 5 days of exposure to illumination followed by 5 days in darkness (L_5d D_5d). All the cultures were placed on the same shaker and maintained at the same temperature $(24 \pm$ $2^{\circ} \mathrm{C}$ ). The photoperiod effect was tested on cell biomass and anthocyanin accumulation after 9 days of culture.

\section{Effect of temperature}

A cell mass of $0.75 \mathrm{~g}$ obtained from the cell culture stock was inoculated into each 100 $\mathrm{mL}$ Erlenmeyer flask containing $20 \mathrm{~mL}$ cell proliferation medium. The $\mathrm{pH}$ of the medium was adjusted to 5.75 before autoclaving. The cell cultures were incubated at three different temperatures: $20 \pm 2^{\circ} \mathrm{C}, 26 \pm 2^{\circ} \mathrm{C}$ and $29 \pm 2^{\circ} \mathrm{C}$. All the cultures were exposed to light intensities maintained within the range of $301-600$ lux. The cell biomass yield, pigment 
content and pigment production were determined after 9 days of culture.

\section{Effect of medium $p H$}

In order to find out the effect of medium $\mathrm{pH}$ on cell yield, pigment content and pigment production, a cell biomass of $0.75 \mathrm{~g}$ obtained from the cell stock was inoculated into each $100 \mathrm{~mL}$ Erlenmeyer flask containing $20 \mathrm{~mL}$ of the cell proliferation medium. The medium was adjusted to different $\mathrm{pH}$ before autoclaving: 4.25, 4.75, $5.25,5.75,5.25$ and 6.75 . All the cultures with different $\mathrm{pH}$ were placed under the light intensities maintained within the range of 301 - 600 lux. The cell biomass yield, pigment content and pigment production were determined after 9 days of culture.

Quantification of pigment content and pigment production

The total anthocyanins, represented by pigment content and pigment production of each culture, were quantified based on its colour (CV)/g-DCM or CV/flask, respectively (CV-Colour value; DCM- Dry Cell Mass; CV/ Flask- colour value per flask). Freeze-dried cells of $80 \mathrm{mg}$ were placed into a specimen bottle and $10 \mathrm{~mL}$ of acidified methanol (methanol $+1 \% \mathrm{HCl} \mathrm{v} /$ $\mathrm{v})$, the best extraction solvent, was added to the cells and stirred. The mixtures were covered and left in the refrigerator at $10^{\circ} \mathrm{C}$ for 24 hours. Absorbance of the supernatant of each sample was determined at wavelength $535 \mathrm{~nm}$ using the Pharmacia Novaspec II Rapid spectrophotometer against the blank which consisted of the solvent. Pigment content, CV/g-DCM, was adapted from Mori et al (1993) as follows:

Pigment content $=0.1 \times$ OD535 $\mathrm{x}$ dilution factor $(\mathrm{CV} / \mathrm{g}-\mathrm{DCM})$

Pigment production, CV/flask, was calculated by multiplying the pigment content with the respective mean dried cell mass obtained at the end of culture.

\section{Statistical analysis}

For each study, seven replicates were used for each factor (light intensity, photoperiod, temperature and medium $\mathrm{pH}$ ) and each study was carried out using a complete randomized design (CRD). Cell biomass yield, pigment content and pigment production were determined after 9 days of culture. The data were analyzed using a one-way ANOVA followed by Duncan's multiple range test for mean comparison at $\mathrm{p}=0.05$.

\section{RESULTS AND DISCUSSION}

Based on the growth index and anthocyanin content, a pigmented cell culture of $M$. malabathricum could be well maintained with an initial inoculum of $0.5 \mathrm{~g}$ of fresh cells inoculated into $20 \mathrm{~mL}$ of liquid MS medium $+0.25 \mathrm{mg} / \mathrm{L} \mathrm{BA}+0.5 \mathrm{mg} / \mathrm{L} \mathrm{NAA}$ in $100 \mathrm{~mL}$ Erlenmeyer flasks and placed on a rotary shaker at $100-120 \mathrm{rpm}$. Most suspension-cultured plant cells fail to detach completely after division, instead they form multi-cellular aggregates (Meyer et al., 2002) and this includes the $M$. malabathricum cultures. During subculture, a sterilized stainless steel sieve with 850 $\mu \mathrm{m}$ pore size was used to separate small cell aggregates from the bigger ones and only the smaller cell aggregates were used for the studies. This is because as cell aggregates enlarge, cells located in the interior of a large cell cluster are not uniformly exposed to nutrients, lighting, oxygen, and other micro-environmental factors, while the younger peripheral cells are. These local concentration gradients could alter cell proliferation, as well as secondary metabolite production.

Cell biomass yield and pigment production of cultures can be affected by several physical factors, including light intensity, photoperiod, temperature and initial medium $\mathrm{pH}$. Experiments on each aspect were carried out to obtain the best condition for high cell biomass yield and pigmentation in cell suspension culture of M. malabathricum.

Light was found to be an important factor that affected biomass yield in cell suspension culture of M. malabathricum. It was also one of the most important factors in inducing and maintaining pigmentation 
in the cells. Light intensities in the range of 301 - 900 lux stimulated growth of culture and lead to achievement of the highest fresh cell mass at the end of culture period. However, the highest pigment production was obtained from cultures exposed to a narrower range of light intensities i.e. 301 600 lux. Very high light intensities of 901 1200 lux reduced the biomass yield by 24 $\%$ and lowered pigment production by 87 $\%$. Thus, light intensity had a stronger effect on pigment production than biomass yield. Incubation of cultures under light intensities of 301 - 600 lux, which produced a 10 -fold increase in pigment production as compared to cultures exposed to light intensities of 0 - 300 lux, was identified as the most suitable for both cell growth and pigment production.

Our results revealed that cultures exposed to low light intensities (below 300 lux $)$, increased cell biomass $(0.85 \pm 0.25 \mathrm{~g}$ fresh and $0.06 \pm 0.02 \mathrm{~g}$ dry). However, the cultures exposed to the light intensity between (301 - 600 lux) had the highest cell biomass $(1.18 \pm 0.04 \mathrm{~g}$ fresh and $0.10 \pm$ $0.01 \mathrm{~g}$ dry). Light intensity (above $901 \mathrm{lux}$ ) subsequently reduced cell biomass $(0.90 \pm$ $0.10 \mathrm{~g}$ fresh and $0.07 \pm 0.01 \mathrm{~g}$ dry). Exposure to medium a range of light intensities of $301-900$ lux stimulated better cell growth as compared to extremely low or high light intensities (Fig. 1).

The effect of exposure to different light intensities was greater on pigment accumulation than on cell growth. At low light intensities (below 300 lux), the cultures produced pigment content of 0.20 $\pm 0.09 \mathrm{CV} / \mathrm{g}-\mathrm{FCM}$ and pigment production of $0.19 \pm 0.13 \mathrm{CV} /$ flask. Medium light intensities (301 - 600 lux), induced higher accumulation of anthocyanins. The cultures exposed to these light intensities showed an increase in pigment content $(1.62 \pm 0.14$ $\mathrm{CV} / \mathrm{g}-\mathrm{FCM}$ ) and pigment production (1.91 $\pm 0.14 \mathrm{CV} / \mathrm{flask})$. The cultures exposed to higher light intensities (601 - 900 lux) showed slight decrease in pigment content $(1.20 \pm 0.52 \mathrm{CV} / \mathrm{g}-\mathrm{FCM})$ and pigment production $(1.38 \pm 0.62 \mathrm{CV} /$ flask $)$ and the highest range of light intensities (above 901 lux) caused a drastic reduction in pigment content $(0.29 \pm 0.10 \mathrm{CV} / \mathrm{g}-\mathrm{FCM})$ and pigment production $(0.27 \pm 0.11 \mathrm{CV} /$ flask $)$. Exposure of cell cultures to extreme light intensities of either 0 - 300 lux or 901 1200 lux inhibited anthocyanin production (Fig. 1).

Experiments on the photoperiod further showed that continuous lighting for 10 days did not induce fresh cell biomass yield as much growth in darkness, which stimulated the highest anthocyanin production. On the other hand, continuous exposure to darkness throughout the cell cycle produced the highest biomass yield, but caused a major loss of pigmentation. Cultures that were exposed to light for 5 days followed by darkness for 5 days, or cultures that received the reverse treatment, produced fresh cell mass that were not significantly different. In terms of anthocyanin accumulation, cultures exposed to darkness, followed by exposure to light, produced better pigment content, suggesting that light exposure at the second half of the cell cycle was more crucial for the accumulation of pigment (Fig. 2). It is reported that lightenhanced production involved photosensory/photoregulation systems as the photoreceptor act as a switch to control the expression of specific genes involved in growth, developmental processes and secondary metabolism in plants (Jenkins et al., 1995; Ahmad et al., 1998; Kurata et al., 2000). In the $M$. malabathricum cell culture, the photoreceptor that control s the expression of genes involved in anthocyanin production could be seen to be triggered by exposure to 301 - 600 lux light intensities. After the process of anthocyanin biosyntheses was stimulated, it took the cells an average of 9 days to achieve maximum pigment content. Light has also been shown to induce anthocyanin biosynthesis in other cultures, such as Camptotheca acuminate (Pasqua et al. 2005). However, in some species, such as Aralia cordata (Sakamoto et al., 1993), Fragaria ananassa (Nakamura et al., 1999) and sweet potato (Konczak- Islam et al., 2000), cell cultures had been reported to produce anthocyanins in the dark.

Temperature has many effects on the mechanisms of metabolic regulation, permeability, nutritional needs, and the rate 
of intracellular reactions in plant cell cultures (Zhang et al., 1997). Thus, changing the culture temperature may change the physiology and metabolism of cultured cells and subsequently affect growth and secondary metabolite production. A temperature range of 17 $25^{\circ} \mathrm{C}$ is normally used for the induction of callus tissues and growth of cultured cells (Rao \& Ravishankar, 2002). However, each plant species may favor a different temperature. Experimentation with cell suspension culture of $M$. malabathricum showed that temperature has a major effect on both cell biomass and anthocyanin accumulation. The cell cultures exposed to
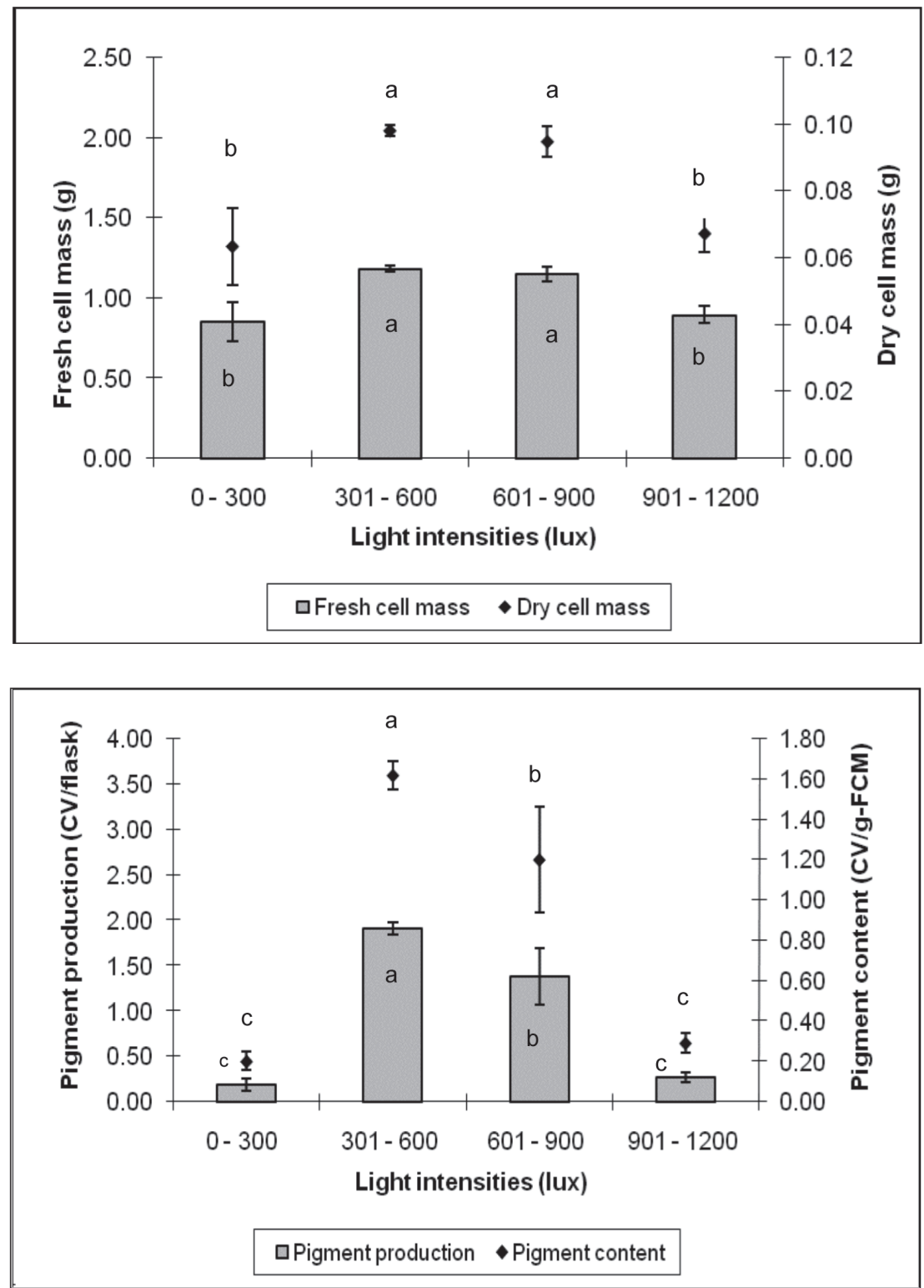

Fig. 1: Effect of light intensities on fresh and dry cell mass (above); pigment content and pigment production (below) of cell suspension culture of $M$. malabathricum L. in liquid MS medium +0.25 $\mathrm{mg} / \mathrm{L} \mathrm{BA}+0.5 \mathrm{mg} / \mathrm{L} \mathrm{NAA}(\mathrm{n}=7)$.

Bars indicate standard deviations.

Means for each parameter having the same letter were not significantly different (Duncan's multiple range test, $\mathrm{p}=0.05$ ). 
the lower temperature range $\left(20 \pm 2^{\circ} \mathrm{C}\right)$ showed the highest increase in cell biomass $(2.49 \pm 0.55 \mathrm{~g}$ fresh and $0.12 \pm 0.02 \mathrm{~g}$ dry $)$ (Fig. 3). Besides producing the highest cell biomass, the cultures incubated at the lower temperature $\left(20 \pm 2^{\circ} \mathrm{C}\right)$ also had the highest pigment production $(1.04 \pm 0.17 \mathrm{CV} /$ flask $)$ and pigment content $(0.42 \pm 0.04 \mathrm{CV} / \mathrm{g}$ FCM). The cultures incubated at $26 \pm 2^{\circ} \mathrm{C}$ and $29 \pm 2^{\circ} \mathrm{C}$ had lower pigment production
(0.20 - $0.24 \mathrm{CV} /$ per flask) and pigment content $(0.21-0.30 \mathrm{CV} / \mathrm{g}-\mathrm{FCM})$, respectively (Fig. 3). An increase of $20^{\circ} \mathrm{C}$ to $26^{\circ} \mathrm{C}$ caused a drop of $53 \%$ in FCM and a drop of $77 \%$ in pigment production. The effect of temperature could be linked to the activity of the enzymes involved in anthocyanin biosynthesis. Cell suspension cultures of Daucus carota showed the highest growth, as well as anthocyanin
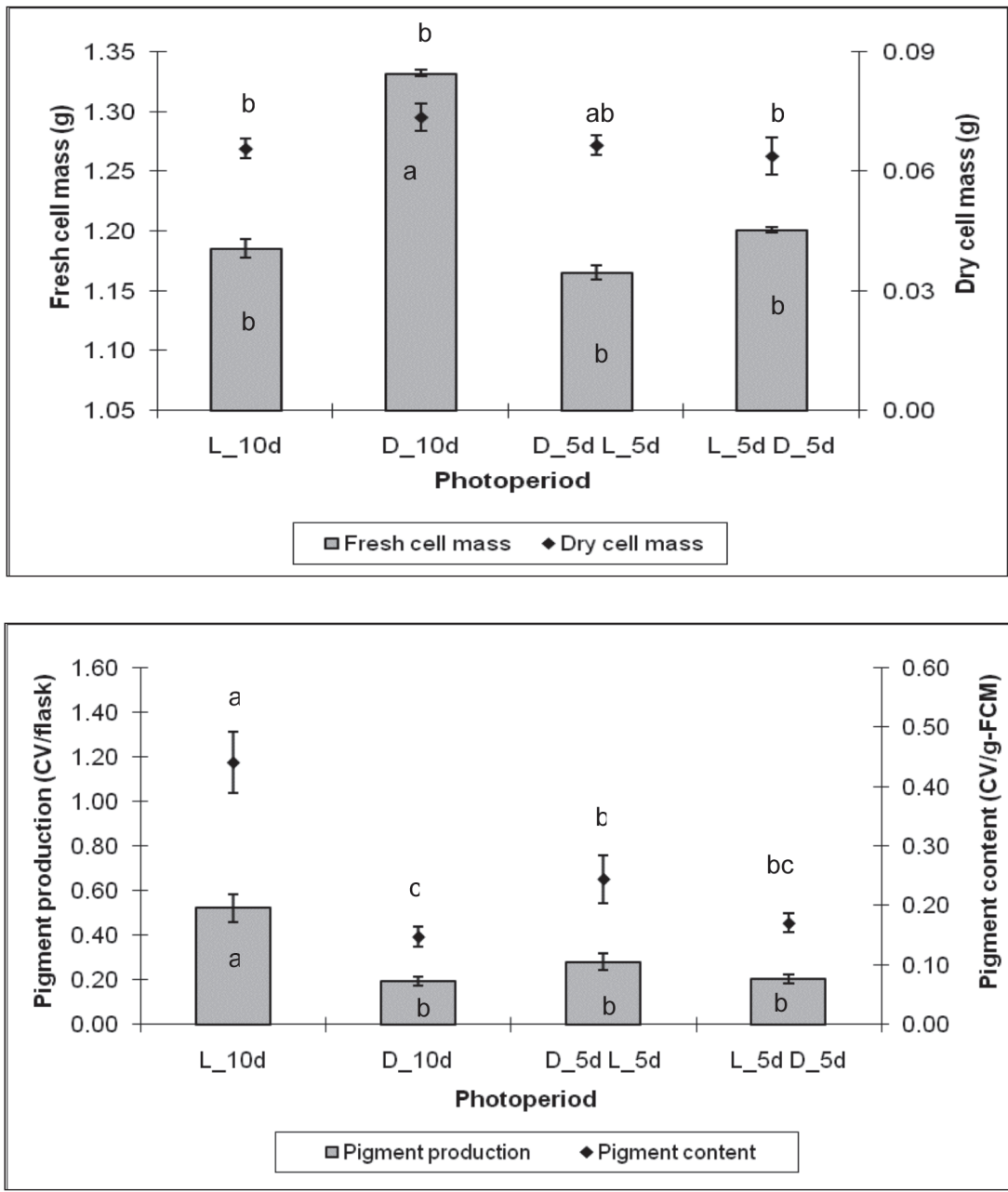

Fig. 2: Effect of photoperiods on fresh and dry cell mass (above); pigment content and pigment production (below) of cell suspension cultures of $M$. malabathricum L. in liquid MS medium + $0.25 \mathrm{mg} / \mathrm{L} \mathrm{BA}+0.5 \mathrm{mg} / \mathrm{L}$ NAA. Bars indicate standard deviations. Means for each parameter having the same letter were not significantly different (Duncan's multiple range test, $p=0.05$ ).

Key:

L_10d: 10 days of continuous illumination;

D_10d:10 days of continuous darkness;

D_5d L_5d: 5 days of continuous darkness followed by 5 days of continuous light;

L_5d D_5d: 5 days of continuous illumination followed by 5 days of continuous darkness. 
content, at $25{ }^{\circ} \mathrm{C}$ in an experiment with temperatures of $20{ }^{\circ} \mathrm{C}, 25^{\circ} \mathrm{C}$ and $30{ }^{\circ} \mathrm{C}$ (Narayan et al., 2005). For strawberry cell culture, maximum anthocyanin content was obtained at $15^{\circ} \mathrm{C}$ and it was about 13 -fold higher than that obtained at $35^{\circ} \mathrm{C}$ (Zhang et al., 1997). For suspended cultures of Perilla frutescens, anthocyanin production was remarkably reduced at the relatively high temperature of $28{ }^{\circ} \mathrm{C}$, and $25^{\circ} \mathrm{C}$ appeared to be optimal for the volumetric productivity of the pigment (Zhong \& Yoshida, 1993).
For cell suspension culture of $M$. malabathricum, different initial medium $\mathrm{pH}$ that were tested $(4.25,4.75,5.25,5.75,6.25$ and 6.75) did not have much effect on the fresh and dry cell mass after 9 days of culture. The cell biomass yield with fresh cell mass of $1.4-1.8 \mathrm{~g}$ and dry cell mass of $0.11-0.12 \mathrm{~g}$ were not significantly different in all the tested $\mathrm{pH}$ ranges (Fig. 4).

Although the initial medium $\mathrm{pH}$ did not show significant effect on biomass yield, it affected anthocyanin accumulation in the
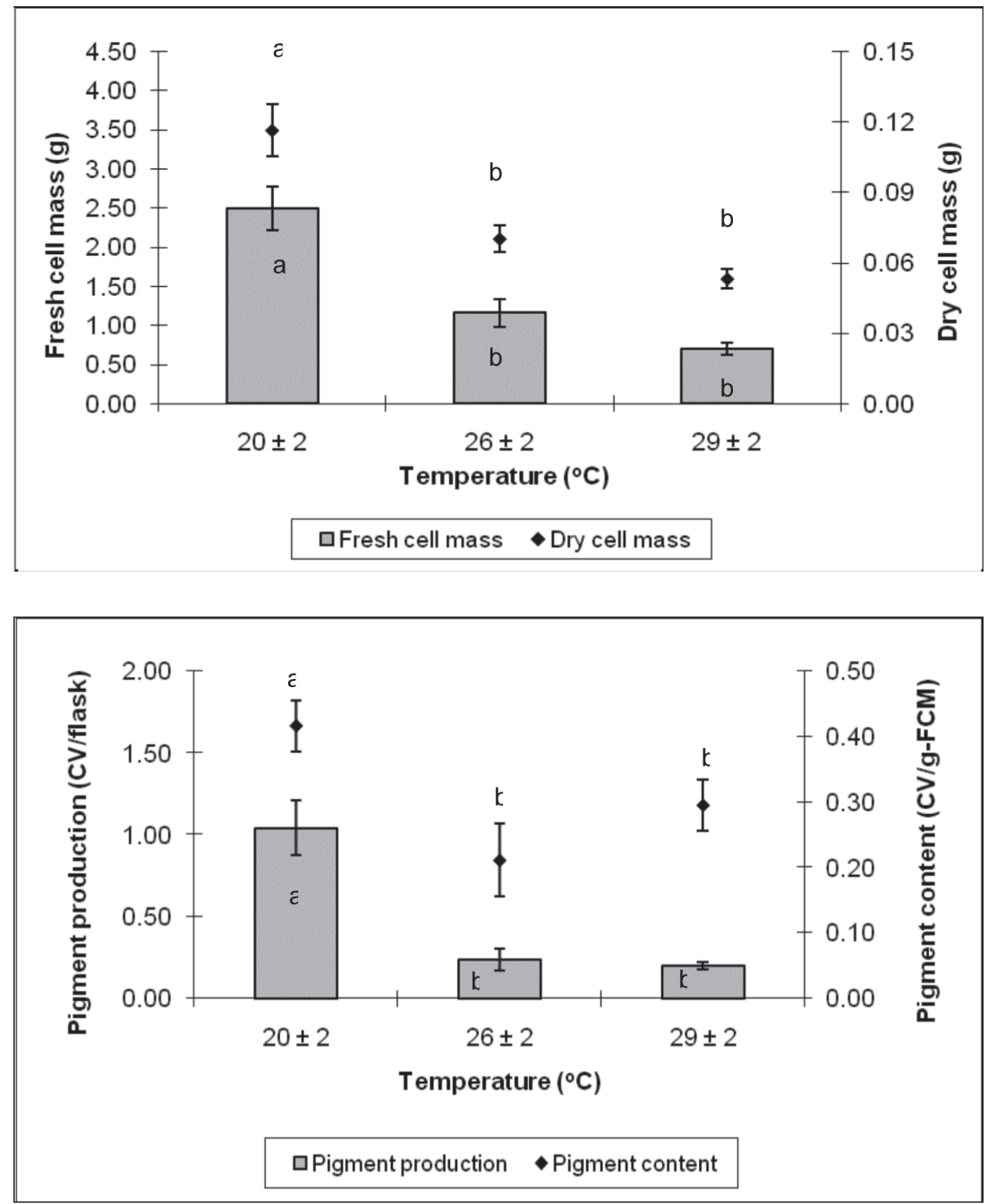

Fig. 3: Effect of temperature on fresh and dry cell mass (above); pigment content and pigment production (below) of cell suspension cultures of M. malabathricum L. in liquid MS medium + $0.25 \mathrm{mg} / \mathrm{L} \mathrm{BA}+0.5 \mathrm{mg} / \mathrm{L}$ NAA after 9 days of culture $(\mathrm{n}=7)$.

Bars indicate standard deviations.

Mean for each parameter having the same letter were not significantly different (Duncan's multiple range test, $\mathrm{p}=0.05)$. 
cell cultures. Cell cultures with initial medium $\mathrm{pH}$ of $5.25-6.25$ achieved higher anthocyanin accumulation, with pigment production of $2.42-2.99 \mathrm{CV} /$ flask and pigment content of $1.71-2.11 \mathrm{CV} / \mathrm{g}-\mathrm{FCM}$. Both values were significantly different $(\mathrm{p}$ $=0.05)$ from cultures in the more acidic or alkaline state. Anthocyanin accumulation with pigment production of $1.46 \mathrm{CV} /$ flask and pigment content of $0.86 \mathrm{CV} / \mathrm{g}-\mathrm{FCM}$, was the lowest for cell cultures in alkaline medium that supported the highest cell mass of $1.80 \pm 0.24 \mathrm{~g}$ ( $\mathrm{pH} 6.75)$ (Fig. 4). Similar result was observed by Luthfi (2004), who found that the $\mathrm{pH}$ of the medium 5.75 (before autoclaving) produced the highest cell biomass and highest total alkaloids in cell suspension culture of Eurycoma longifolia.

The present study found that different
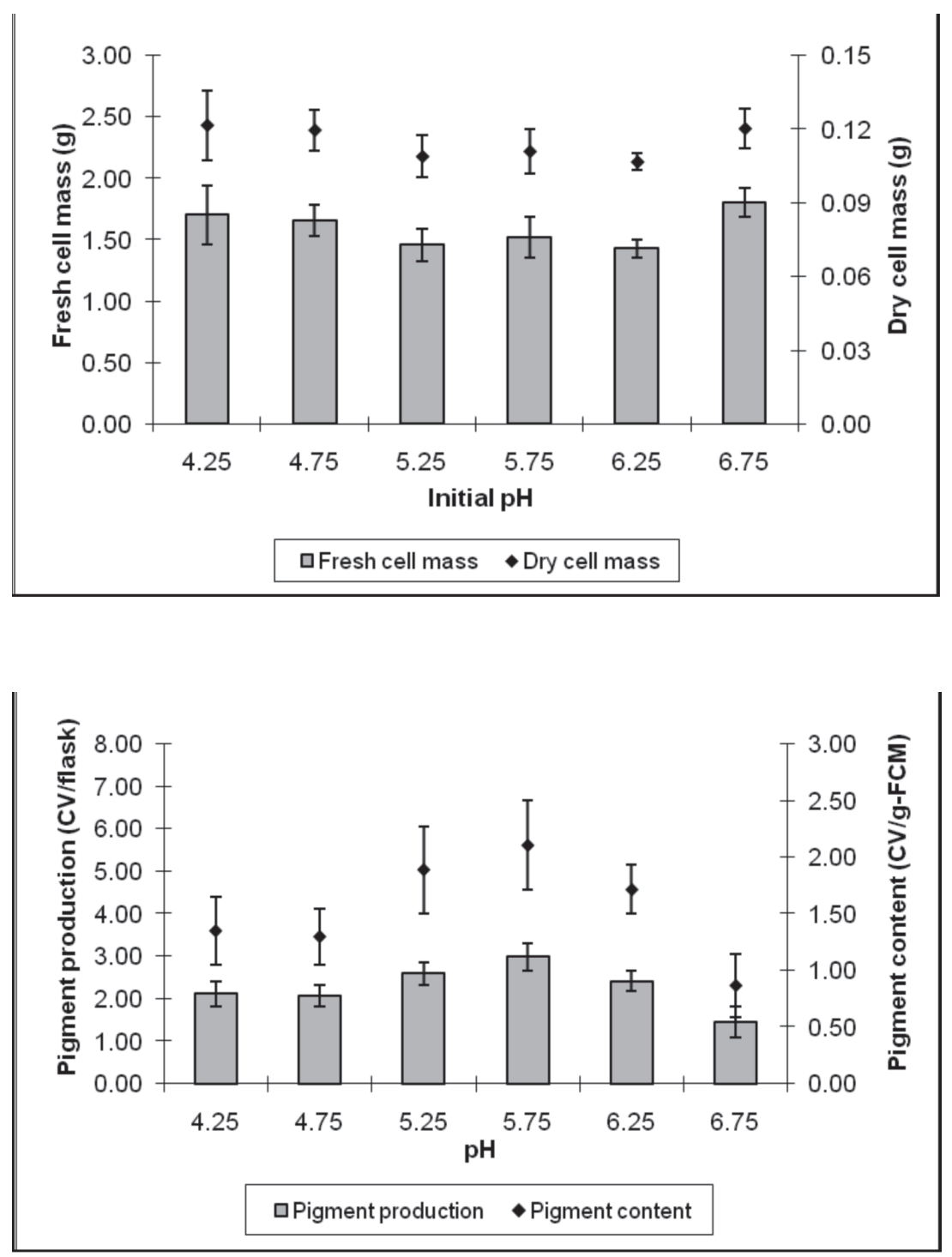

Fig. 4: Effect of medium $\mathrm{pH}$ on fresh and dry cell mass (above); pigment content and pigment production (below) of cell suspension cultures of $M$. malabathricum $\mathrm{L}$. in liquid MS medium + $0.25 \mathrm{mg} / \mathrm{L} \mathrm{BA}+0.5 \mathrm{mg} / \mathrm{L} \mathrm{NAA}$ after 9 days of culture $(\mathrm{n}=7)$.

Bars indicate standard deviations.

Means for each parameter having the same letter were not significantly different (Duncan's multiple range test, $\mathrm{p}=0.05$ ). 
factors, such as light intensity, irradiance, temperature and medium $\mathrm{pH}$ affect cell biomass yield and anthocyanin production in M. malabathricum. The exposure of cell cultures of M. malabathricum to the lower range (301 - 600 lux) of light intensities and continuous irradiance for 10 days could be used for higher pigment production. The lowest range of temperature i.e., $20 \pm 2^{\circ} \mathrm{C}$ was found effective in production of the highest fresh cell mass, dry cell mass and pigment production. Cell cultures with initial medium $\mathrm{pH}$ of 5.25 - 6.25 showed higher anthocyanin accumulation in $M$. malabathricum.

\section{CONCLUSION}

To produce high cell mass and high anthocyanin content from $M$. malabathricum cells, the cell cultures have to be cultured in MS medium supplemented with $0.25 \mathrm{mg} \mathrm{dm}^{-3}$ benzyladenine (BA) and $0.5 \mathrm{mg} / \mathrm{L}$ NAA with $\mathrm{pH}$ adjusted to 5.75 and maintained at a temperature of $20 \pm$ $2^{\circ} \mathrm{C}$, with exposure to continuous light, with light intensity in the range of $301-600$ lux.

\section{ACKNOWLEDGEMENT}

We thank Universiti Sains Malaysia Fellowship Scheme for financial support and School of Biological Sciences for research facilities.

\section{REFERENCE}

Ahmad M, Jarillo JA, Smirnova O, Cashmore AR (1998) The CRY-1 blue light photoreceptor of Arabidopsis interacts with phytochrome A in vitro. Molecular Cell 1: 939-948

CHAN LK, SEE KS, HOON LP, LIM BP (2008) Effect of plant growth regulators and subculture frequency on callus culture and the establishment of Melastoma malabathricum cell suspension culture for the production of pigments. Biotechnology 7(4): 678-685.

DELGADO-VARGAS F, PARADES-LOPEZ O (2003) Natural Colorants for Food and Nutraceutical Uses. CRC Press, Boca Raton, Florida.

DEROLES SC,EJJAVELLANA JM,ÊLEWIS DH,ÊARATHOON HS (2006) Modification of Anthocyanin Biosynthesis in Plant Cell Cultures.Ê4th
International Workshop of Anthocyanins, Royal Lakeside Novotel, Rotorua, 14-17 February, 2006 International Workshop on Anthocyanins: 23.

FILIPPINI R, CANIATO R, PIOVAN A, CAPPELLETTI EM (2003) Production of anthocyanins by Catharanthus roseus. Fitoterapia 74: 62-67.

JENKINS GI, CHRISTIE JM, FUGLEVANC G, LONG JC, JACKSON JA (1995) Plant response to UV and blue light: biochemical and genetic approaches. Plant Sci 112: 117-138.

KONCZAK-ISLAM I, YOSHINAGA M, NAKATANI M, ERAHARA N, YAMAKAWA O (2000) Establishment and characteristics of an anthocyanin-producing cell line from sweet potato storage root. Plant Cell Rep 19: 472-477.

KURATA H, MOCHIZUKI A, OKUDA N, SEKI M, FURUSAKI S (2000) Intermittent light irradiation with second- or hour-scale periods controls anthocyanin production by strawberry cells. Enzyme Microb Technol 26: 621-629.

LUTHFI AMS (2004) Pengoptimuman kultur ampaian sel Eurycoma longifolia Jack untuk penghasilan biojisim dan alkaloid. Ph. D. Thesis. Universiti Sains Malaysia. Penang, Malaysia

MAZZA G (2000) Health aspects of natural colors. - In: Lauro, G.J., Francis, F.J. (ed.). Natural Food Colorants - Science and Technology, MarcelDekker, Inc.

MEYER JL, PÉPIN MF, SMITH MAL (2002). Anthocyanin production from Vaccinium pahalae: limitations of the physical microenvironment. J Biotechnol. 93: 45-57.

MORI T, SAKURAI M, SHIGETA J, YOSHIDA K, KONDO T (1993) Formation of anthocyanins from cells cultured from different parts of strawberry plants. J Food Sci 58: 788-792.

MURASHIGE T, SKOOG F (1962) Revised medium for rapid growth and bioassays with tobacco tissue cultures. Pysiol Plant 15: 473-497.

NAKAMURA M, TAKEUCHI Y, MIYANAGA K, SEKI M, FURUSAKI S (1999) High anthocyanin accumulation in the dark by strawberry (Fragaria ananassa) callus. Biotechnol Lett 21: 695-699.

NARAYAN MS, THIMMARAJU R, BHAGYALAKSHIMI (2005) Interplay of growth regulators during solid-state and liquid-state batch cultivation of anthocyanin producing cell line of Daucus carota. Process Biochem. 40: 351-358.

PASQUA G, MONACELLI B, MULINACCI N, RINALDI $\mathrm{S}$, GIACCHERINI C, INNOCENTI M, VINCERI FF (2005) The effect of growth regulators and sucrose on anthocyanin production in Camptotheca acuminate cell cultures. Plant Physiol Biochem 43: 293-298.

RAO R, RAVISHANKAR GA (2002) Plant cell cultures: chemical factories of secondary metabolites. Biotechnol Adv. 20: 101-153.

TERAHARA N, KONCZAK I, ONO H, YOSHIMOTO M, YAMAKAWA O (2004) Characterization of acylated anthocyanins in callus induced from storage root of purple-fleshed sweet potato, Ipomoea batatas L. Journal of Biomedicine and Biotechnology 5: 279-286.

ZHANG W, SEKI M, FURUSAKI S (1997) Effect of temperature and its shift on growth and anthocyanin production in suspension cultures of strawberry cells. Plant Sci 127: 207-214.

ZHONG J, YOSHIDAT (1993) Effects of temperature on cell growth and anthocyanin reduction in suspension cultures of Perilla frutescens. J Ferment Bioeng 76: 530-531. 
